\title{
Platelet Receptor-mediated Factor X Activation by Factor IXa High-Affinity Factor IXa Receptors Induced by Factor VIII Are Deficient on Platelets in Scott Syndrome
}

Syed S. Ahmad, Razia Rawala-Sheikh, Barrie Ashby, and Peter N. Walsh

Thrombosis Research Center, Departments of Medicine and Biochemistry,

Temple University School of Medicine, Philadelphia, Pennsylvania 19140

\begin{abstract}
We have studied factor IXa binding and factor $\mathrm{X}$ activation with normal platelets and with platelets obtained from a patient with a bleeding disorder and an isolated deficiency of platelet procoagulant activity termed Scott syndrome. In the absence of factor VIIIa and factor $X$, normal, thrombin-treated platelets exposed $560 \pm 35$ sites for factor IXa with a $K_{d}$ of $2.75 \pm 0.27 \mathrm{mM}$, compared with $461 \pm 60$ sites per patient platelet with $K_{d}$ of $3.2 \pm 0.33 \mathrm{nM}$. The addition of factor VIIIa and factor $X$ resulted in a decrease in the $K_{d}$ for normal platelets to $0.68 \mathrm{nM}$ but had no effect on the $K_{d}$ for patient platelets. The concentrations of factor IXa required for half-maximal rates of factor $X$ activation for normal $(0.52 \mathrm{nM})$ and patient platelets (2.5 $\mathrm{nM})$ were similar to those determined from equilibrium binding studies. Kinetic parameters for factor $\mathbf{X}$ activation by factor IXa showed that the $\boldsymbol{K}_{\mathrm{m}}$ and $\boldsymbol{k}_{\text {cat }}$ were identical for normal and patient platelets in the absence of factor VIIIa. In the presence of factor VIIIa, and $k_{\text {cat }}$ for patient platelets (163 $\mathrm{min}^{-1}$ ) was only $33 \%$ of that for normal platelets (491 $\mathrm{min}^{-1}$ ): This result can be explained by the difference in affinity for factor IXa between normal and patient platelets in the presence of factor VIIIa, suggesting impaired factor VIIIa binding to Scott syndrome platelets.
\end{abstract}

\section{Introduction}

Platelets promote the catalysis of two sequential, calcium-dependent reactions in blood coagulation: the activation of factor X by a complex of factor IXa and factor VIIIa (1-6) and the conversion of prothrombin to thrombin by a complex of factor $\mathrm{Xa}$ and factor $\mathrm{Va}(7-12)$. The contribution of platelets to prothrombin activation is receptor mediated, since platelets possess specific, high-affinity, saturable binding sites for factor $\mathrm{Xa}(7,10)$ and factors $\mathrm{V}$ and $\mathrm{Va}(11,12)$ and receptor occupancy is closely correlated with rates of prothrombin activation (7-12). Recently we have demonstrated that activated human platelets also have specific, saturable receptors for factor IXa involved in factor X activation (13). The presence of

Address reprint requests to Dr. Walsh.

Received for publication 10 February 1989 and in revised form 28 March 1989.

\footnotetext{
J. Clin. Invest.

(c) The American Society for Clinical Investigation, Inc.

0021-9738/89/09/0824/05 $\$ 2.00$

Volume 84, September 1989, 824-828
}

factor VIII, which also binds to specific, high-affinity sites on activated platelets (14), together with factor X, increases fivefold the affinity of factor IXa binding to activated platelets (13). In order to investigate in more detail the mechanism of factor $\mathrm{X}$ activation by platelet-bound factor IXa, we have carried out studies of factor IXa binding and factor $\mathrm{X}_{\text {, }}$ activation with normal platelets and with platelets obtained from a patient with a bleeding disorder termed Scott syndrome $(15,16)$. These platelets, which have previously been shown to have an isolated deficiency of platelet procoagulant activity (15), lack factor Xa binding sites (17) and are deficient both in their capacity to promote prothrombin activation $(17,18)$ and factor $X$ activation (18) and to expose phosphatidylserine at the outer surface of stimulated platelets (18).

\section{Methods}

Platelets. Gel-filtered platelets were isolated as described previously (13). The patient, MS, who has been reported in detail by Weiss et al. (15), is a 45-yr-old woman with a moderate bleeding disorder now referred to as Scott syndrome (16). She visited Philadelphia and her platelets were studied on three separate occasions in direct comparison with control platelets adjusted to the same platelet count.

Purification of proteins. Factor IX (333 U/mg) was purified to apparent homogeneity from human plasma by immunoaffinity chromatography and was converted to factor IXa by incubation with purified factor XIa as previously described (13). Factor IX was radiolabeled with ${ }^{125}$ I by the Iodogen method (19), as previously described (13). The majority of the free ${ }^{125} \mathrm{I}$ was then separated from the protein by passage through a 1-ml G-25 column (20), and the labeled protein was further dialyzed in the presence of ovalbumin $(1 \mathrm{mg} / \mathrm{ml})$. Purified human factor $\mathrm{X}$ had a specific activity of $225 \mathrm{U} / \mathrm{mg}$ and appeared as a single band with an apparent molecular weight of 72,000 on nonreduced SDS gels as reported previously (13). Purified human factor VIII, kindly provided by Dr. J. E. Brown (Cutter Biological, Miles, Inc., Berkeley, CA), had a specific activity of $1,850 \mathrm{U} / \mathrm{mg}$, was devoid of von Willebrand factor antigen, and consisted of protein bands with molecular masses of $230,92,80$, and $40 \mathrm{kD}$ on SDS-PAGE as previously described (13). The factor VIII activity was increased 38-fold in $1 \mathrm{~min}$ by incubation of the protein with $0.05 \mathrm{U} / \mathrm{ml}$ of human $\alpha$-thrombin, was stable for $\sim 3$ min and remained within $50 \%$ of its maximal activity for at least $10 \mathrm{~min}$, during which time all binding and factor $\mathrm{X}$ activation experiments were completed.

Binding experiments. These were carried out as reported in detail earlier (13) in triplicate on three separate occasions using platelets obtained from MS and from three separate normal donors. Saturation binding data were analyzed by the method of Scatchard (21) as previously reported using linear regression analysis and assuming a single class of binding sites.

Measurement of rates of factor Xa formation. Activation of factor X by factor IXa in the presence of stimulated platelets either in the presence or absence of factor VIIIa (for further experimental condi- 
tions, see figure legends) was monitored in incubation mixtures containing platelets, factor $\mathrm{IXa}, \mathrm{CaCl}_{2}$, and thrombin at $37^{\circ} \mathrm{C}$ for $10 \mathrm{~min}$ in a buffer containing $50 \mathrm{mM}$ Tris- $\mathrm{HCl}, 175 \mathrm{mM} \mathrm{NaCl}$, and $0.5 \mathrm{mg} / \mathrm{ml}$ human serum albumin (pH 7.4). Excess thrombin was neutralized with $50 \mathrm{nM}$ D-Phe-Pro-Arg-chloromethylketone (PPACK,' Calbiochem-Behring Corp., San Diego, CA) prior to the addition of factor VIIIa and factor $\mathrm{X}$ to the reaction mixture. After $3 \mathrm{~min}$ (presence of factor VIIIa) or $10 \mathrm{~min}$ (absence of factor VIIIa) at $37^{\circ} \mathrm{C} 10 \mathrm{mM}$ EDTA was added to prevent further activation of factor $\mathrm{X}$ by factor IXa. During this time period rates of factor $\mathrm{Xa}$ formation were linear.

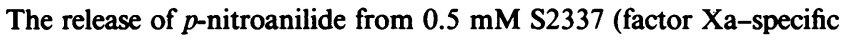
chromogenic substrate from AB Kabi Diagnostica, Stockholm, Sweden) by factor $\mathrm{Xa}$ was followed for $10 \mathrm{~min}$, during which period the rates of cleavage of $\mathbf{2} 2337$ were linear. The reaction was stopped by the addition of glacial acetic acid (5.2\% final concentration) and the amount of pNA released was measured at $405 \mathrm{~nm}$ in a 96-well microtiter plate (No. 3075 plates, Falcon Labware, Oxnard, CA) using a Vmax Kinetic Microplate Reader (Molecular Devices, Palo Alto, CA). Factor IXa alone had no amidolytic activity against S2337. From a calibration curve made with known amounts of factor Xa under the same conditions as described above, the amount of factor Xa present in the aliquot was calculated. The rates of factor Xa formation in the reaction mixture were calculated from the amounts of factor Xa present in the samples. The amount of factor IXa present in the incubation mixture was chosen such that $<10 \%$ of added factor $\mathrm{X}$ was converted to factor Xa during the time course of the experiment.

Calculation of kinetic constants. The derivation of kinetic constants for factor X activation by factor IXa was based on a one-enzyme, one-substrate model. Values for the Michaelis constant $\left(K_{\mathrm{m}}\right)$ and the maximum velocity $\left(V_{\max }\right)$ were calculated from the mean \pm standard error of the mean of three independent determinations by the Lineweaver-Burk method (22) and were calculated by using least-squares fit and the FORTRAN program of Cleland (23) with a TRS 80 computer. Values of kinetic constants obtained by the Cleland program and by graphical analysis were in close agreement (i.e., within 5\%). The apparent dissociation constant for factor IXa binding to platelets was also determined from kinetic measurements of factor $\mathrm{Xa}$ formation by treating factor IXa binding to its receptor as a simple adsorption isotherm in which the concentration of the variable ligand (factor IXa) is well in excess of the other reactant (the factor IXa binding site). Under these conditions the binding constant could be determined from a linear transformation of a simple hyperbola expressing factor $\mathrm{X}$ conversion versus factor IXa concentration. Justification for this approach is as follows. The concentration of factor $\mathrm{X}$ is sufficiently high that $<10 \%$ is transformed to factor Xa during the time of assay at any concentration of factor IXa. Consequently, the concentration of factor $\mathbf{X}$ is essentially constant, always saturating, and its effect on factor IXa binding does not change. The rate of factor $\mathrm{Xa}$ formation is linear and is proportional to the fraction of factor IXa bound to the receptor since binding to the receptor is required to give a significant rate of factor $\mathrm{X}$ conversion (13). The concentration of receptor can be calculated as follows, assuming about 500 receptor sites per platelet. The platelet count is $5 \times 10^{7} / \mathrm{ml}$ or $5 \times 10^{10} /$ liter, so that the total number of receptors per liter is $2.5 \times 10^{13}$. Dividing by Avogadro's number gives about $0.04 \mathrm{nM}$ receptor. This is well below the dissociation constant (13) for factor IXa binding ( 0.5 to $2.5 \mathrm{nM})$ so that the concentration of free factor IXa can be considered equal to the total concentration of factor IXa. As a result it is not necessary to analyze the curves by quadratic expressions $(24,25)$ that take into account a reduction in factor IXa concentration through its binding to receptor.

\section{Results and Discussion}

We have previously demonstrated that ${ }^{125}$ I-labeled factor IXa binds in a saturable and reversible manner to thrombin-acti-

1. Abbreviation used in this paper: PPACK, D-phenylalanylprolylarginyl chloromethyl ketone. vated platelets and that equilibrium is attained in 5-10 min. Scatchard analysis indicated the presence of 515 sites per platelet with a $K_{\mathrm{d}}$ of $2.68 \mathrm{nM}$ in the absence of factor VIIIa and factor X, and 551 sites per platelet with a $K_{\mathrm{d}}$ of $0.56 \mathrm{nM}$ in the presence of factor VIIIa and factor X. Both factor VIIIa and factor $\mathrm{X}$ were required to give the observed fivefold increase in affinity for factor IXa, indicating that perhaps a complex of these two proteins modified an existing binding site for factor IXa (13). In the present work, we have compared binding of ${ }^{125}$ I-labeled factor IXa to normal platelets with binding to Scott syndrome platelets (Fig. $1 A$ ). With normal platelets we obtained 560 sites per platelet with a $K_{\mathrm{d}}$ of $2.75 \mathrm{nM}$ in the absence of factor VIIIa and X; and 538 sites per platelet with a $K_{\mathrm{d}}$ of $0.68 \mathrm{nM}$ in the presence of factor VIIIa and factor $\mathrm{X}$, in excellent agreement with our previous findings (13). With Scott syndrome platelets we obtained 461 sites per platelet with a $K_{\mathrm{d}}$ of $3.2 \mathrm{nM}$ in the absence and 412 sites per platelet with a $K_{\mathrm{d}}$ of $2.5 \mathrm{nM}$ in the presence of factor VIIIa and factor $X$. The most significant difference observed between normal and Scott syndrome platelets was the absence of enhanced affinity of binding of factor IXa induced by factor VIIIa and factor $\mathrm{X}$ in the patient platelets (Fig. $1 A$ and Table I).

In this study we also determined an apparent $K_{\mathrm{d}}$ for factor IXa binding by kinetic studies of factor Xa formation in the presence of saturating factor $\mathrm{X}$ and factor VIIIa (Fig. $1 B$ ). The kinetic approach gave similar results to the binding studies (13) and its use is justified under Methods. Hence, kinetic studies were performed in the presence of saturating levels of factor X and factor VIIIa. The apparent $K_{\mathrm{d}}$ was determined as $0.52 \mathrm{nM}$ for normal platelets and $2.5 \mathrm{nM}$ for Scott syndrome platelets, indicating again that the affinity of the patient platelets for factor IXa was not enhanced by factor $\mathrm{X}$ and factor VIIIa (Fig. $1 B$ and Table I).

We also determined the kinetic parameters for factor $\mathrm{X}$ activation by factor IXa in the presence of normal or patient platelets either in the absence (Fig. $2 \mathrm{~A}$ ) or presence (Fig. $2 \mathrm{~B}$ ) of thrombin-activated factor VIII. Studies were performed at a factor IXa concentration of $0.01 \mathrm{nM}$, which is well below the apparent dissociation constant for binding of factor IXa to normal or patient platelets. In the absence of factor VIIIa, the $K_{\mathrm{m}}$ and $k_{\text {cat }}$ were almost identical for normal and patient platelets (Table I). In contrast, in the presence of saturating concentrations of factor VIIIa, while the $\mathrm{K}_{\mathrm{m}}$ for patient platelets decreased from 0.5 to $0.11 \mu \mathrm{M}$ in a manner comparable to normal platelets, the $k_{\text {cat }}$ for the patient's platelets $\left(163 \mathrm{~min}^{-1}\right)$ was only $33 \%$ of that for normal platelets $\left(491 \mathrm{~min}^{-1}\right)$. This finding can be explained by the difference in affinity for factor IXa between normal and patient platelets in the presence of factor VIIIa. Hence, assuming hyperbolic binding of factor IXa that is directly related to the rate of factor Xa formation, the velocity $(v)$ at saturating factor $\mathrm{X}$ can be determined from the expression: $v=V_{\max } \cdot[I X a] /\left(K_{\mathrm{d}}+[I X a]\right)$, where $V_{\max }$ is the velocity obtained at saturating factor IXa concentration (and saturating factor $\mathrm{X}$ ) and $K_{\mathrm{d}}$ is the dissociation constant for binding of factor IXa to platelets.

In normal platelets, in the presence of factor VIIIa, $K_{\mathrm{d}}$ is $0.52 \mathrm{nM}$ and at $0.01 \mathrm{nM}$ factor IXa, v can be calculated as $1.9 \%$ of $V_{\max }$. For patient platelets under the same conditions, $v$ is $0.4 \%$ of $V_{\max }$. Hence, at $0.01 \mathrm{nM}$ factor IXa, the velocity determined at saturating factor $\mathrm{X}$ for patient platelets would be expected to be $100 \times 0.4 / 1.9$ or $21 \%$ of that determined for normal platelets, which is close to the value of $33 \%$ that is 


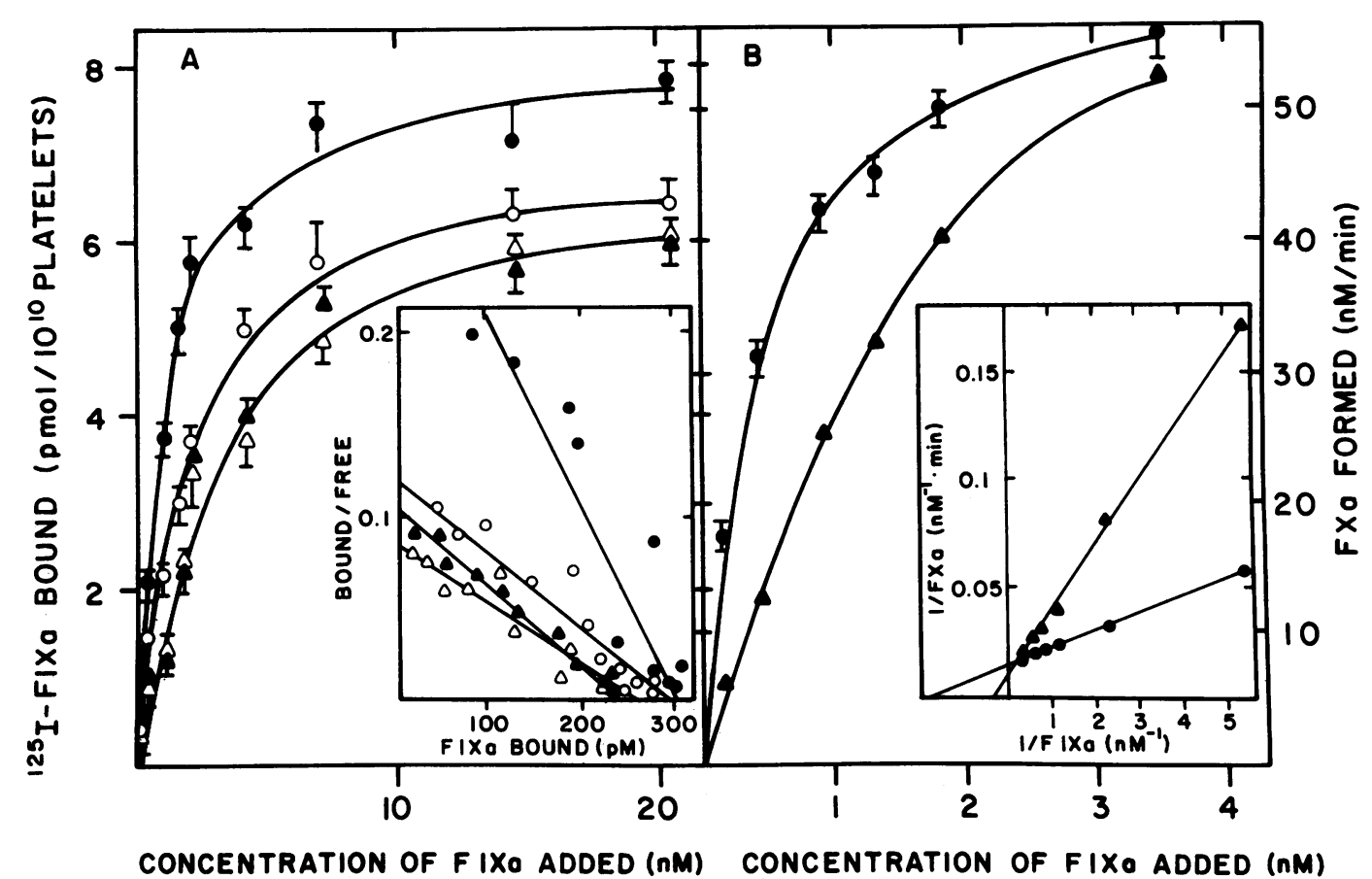

CONCENTRATION OF FIXO ADDED (nM) CONCENTRATION OF FIXO ADDED (nM)

Figure 1. (A) Specific binding of ${ }^{125} \mathrm{I}$-factor IXa to thrombin-activated normal human platelets and in Scott syndrome in the absence and presence of factor VIIIa and factor X. Gel-filtered platelets $\left(3.5 \times 10^{8} / \mathrm{ml}\right)$ were incubated at $37^{\circ} \mathrm{C}$ with human $\alpha$-thrombin $(0.1$ $\mathrm{U} / \mathrm{ml}$ ), $\mathrm{CaCl}_{2}$ (5 mM), and ${ }^{125} \mathrm{I}$-factor IXa in the presence or absence of thrombin-activated factor VIII $(5 \mathrm{U} / \mathrm{ml})$ and factor $\mathrm{X}(1.5 \mu \mathrm{M})$. Binding was determined as detailed under Methods. Nonspecific binding was determined in the presence of excess unlabeled factor IXa $(0.44 \mu \mathrm{M} ; 25$ $\mu \mathrm{g} / \mathrm{ml}$ ) and was subtracted from total bind-

ing to obtain specific binding. The results shown represent specific binding of factor IXa in the absence (0) or presence (•) of factor VIIIa and factor X to normal platelets and in Scott syndrome in the absence $(\Delta)$ and presence $(\Delta)$ of factor VIIIa and factor X. Results represent means \pm SEM for three separate experiments done on three separate days with three separate normal donors. (Inset) Scatchard plot of the same data including data obtained at higher ligand concentration. $(B)$ Rates of factor Xa formation by factor IXa in the presence of thrombin-activated platelets and factor VIIIa. The rate of activation of human factor $\mathrm{X}$ by varying concentrations $(0.17-3.5 \mathrm{nM})$ of factor IXa was determined in the presence of $5 \times 10^{7} / \mathrm{ml}$ stimulated platelets in $37^{\circ} \mathrm{C}$ in a reaction volume of $100 \mu$ containing $50 \mathrm{mM} \mathrm{Tris} \mathrm{(pH} \mathrm{7.9),} \mathrm{175} \mathrm{mM}$ $\mathrm{NaCl}, 5 \mathrm{mM} \mathrm{CaCl}, 1.5 \mu \mathrm{M}$ factor X, $5 \mathrm{U} / \mathrm{ml}$ of factor VIII, and $0.5 \mathrm{mg} / \mathrm{ml}$ human serum albumin. Platelets were stimulated with $0.1 \mathrm{U} / \mathrm{ml}$ thrombin in the presence of $\mathrm{CaCl}_{2}(5 \mathrm{mM})$, and factor IXa was preincubated with platelets for $10 \mathrm{~min}$ at $37^{\circ} \mathrm{C}$. Excess thrombin was neutralized with $50 \mathrm{nM}$ PPACK before addition of factor VIIIa and performance of the assay. For experimental details, see Methods. The results presented are the means \pm SEM of duplicate observations with platelets from three separate normal donors $(\bullet)$ and means of duplicate observations with MS platelets ( $\triangle$ ). (Inset) Double reciprocal plot of the same data.

actually observed. By this reasoning, the rates of factor $\mathrm{Xa}$ formation by both normal and patient platelets should be identical when the factor IXa site is saturated. This is borne out by the data in Fig. $1 B$ that shows the same rate of factor $\mathrm{Xa}$ formation by normal and patient platelets as factor IXa approaches saturation. Moreover, we have actually calculated the turnover numbers for factor $X$ activation by factor IXa bound to normal or patient platelets from the data presented in Fig. $1 A$ and $B$. Thus, at five different concentrations of added factor IXa (0.44-3.5 $\mathrm{nM})$ the rates of factor Xa formed (in picomoles per $10^{9}$ platelets per minute, Fig. $1 B$ ) were divided by the amounts of factor IXa bound (in picomoles per $10^{9}$ platelets, Fig. $1 \mathrm{~A}$ ). The resulting turnover numbers (in moles of factor Xa formed per mole of factor IXa bound per minute) were independent of enzyme concentration, as they should be at saturating substrate concentration. Furthermore, the mean ( \pm SEM, $n=5$ ) value for normal platelets was 2,280 $( \pm 138)$, compared with $2,361( \pm 88)$ for Scott syndrome platelets.

Our studies were carried out at a single concentration of factor VIIIa $(5 \mathrm{U} / \mathrm{ml})$, which is near the plasma concentration of factor VIII. This concentration of factor VIII has been

Table I. Kinetic Parameters and Binding Constants for Normal and Scott Syndrome Platelets

\begin{tabular}{|c|c|c|c|c|c|c|c|c|c|}
\hline \multirow[b]{2}{*}{ Platelets } & \multirow[b]{2}{*}{ Factor VIII } & \multirow[b]{2}{*}{$\begin{array}{c}\text { Number of sites } \\
\text { per platelet }\end{array}$} & \multicolumn{2}{|l|}{$K_{d}$} & \multirow[b]{2}{*}{$K_{\mathrm{m}}$} & \multirow[b]{2}{*}{$k_{\text {catt }}{ }^{*}$} & \multirow[b]{2}{*}{$k_{\text {catt }}{ }^{*}$} & \multirow[b]{2}{*}{$k_{\text {cat }} * / K_{\mathrm{m}}$} & \multirow[b]{2}{*}{$k_{\mathrm{cm}^{\ddagger}}^{\ddagger} / K_{\mathrm{m}}$} \\
\hline & & & Equilibrium & Kinetic & & & & & \\
\hline & & & \multicolumn{2}{|l|}{$n M$} & $\mu M$ & & $\min ^{-1}$ & \multicolumn{2}{|c|}{$\mu M^{-1} \cdot \min ^{-1}$} \\
\hline \multirow[t]{2}{*}{ Normal } & Absent & $560( \pm 35)$ & $2.75( \pm 0.27)$ & & 0.5 & 0.25 & & 0.5 & \\
\hline & Present & $538( \pm 50)$ & $0.68( \pm 0.07)$ & 0.52 & 0.104 & 491 & $2,280( \pm 138)$ & 4,721 & 21,923 \\
\hline \multirow[t]{2}{*}{ Scott syndrome } & Absent & $461( \pm 60)$ & $3.2( \pm 0.33)$ & & 0.59 & 0.29 & & 0.49 & \\
\hline & Present & $412( \pm 44)$ & $2.5( \pm 0.19)$ & 2.5 & 0.11 & 163 & $2,361( \pm 88)$ & 1,482 & 21,463 \\
\hline
\end{tabular}

Results presented represent means $( \pm \mathrm{SEM})$ of three separate determinations. $\quad k_{\text {cat }}{ }^{*}$ is expressed as moles of factor Xa formed per mole of total factor IXa per minute. $\quad k_{\text {cat }}{ }^{\ddagger}$ is expressed as moles of factor Xa formed per mole of platelet-bound factor IXa per minute. See text for explanation. 


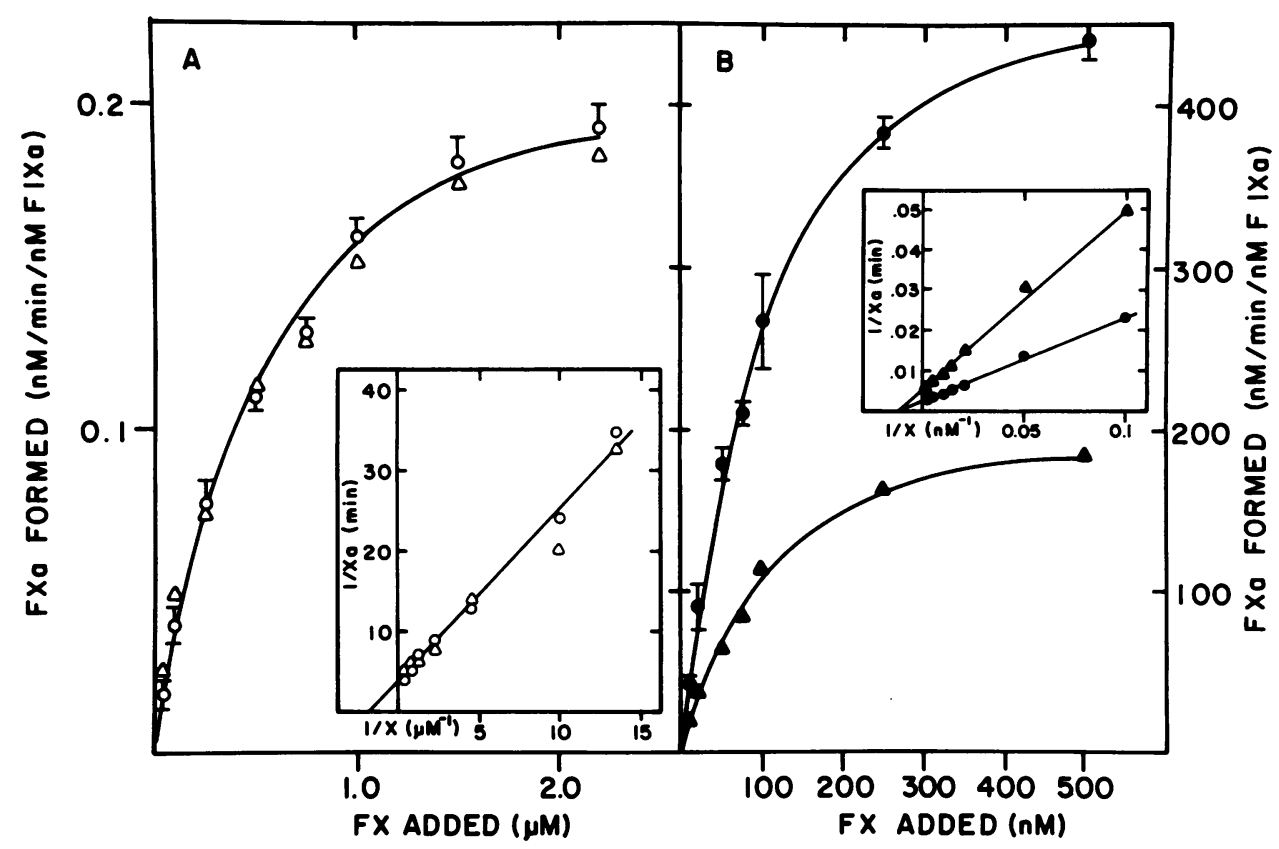

Figure 2. (A) Factor Xa formation by factor IXa in the presence of thrombin-activated platelets and absence of factor VIIIa. Thrombinstimulated $(0.1 \mathrm{U} / \mathrm{ml})$, gel-filtered platelets $\left(5 \times 10^{7} / \mathrm{ml}\right)$ were preincubated with factor IXa $(0.01 \mu \mathrm{M})$ and $5 \mathrm{mM} \mathrm{CaCl}_{2}$ at $37^{\circ} \mathrm{C}$ for 10 $\mathrm{min}$, and with $50 \mathrm{nM}$ PPACK for 2 $\min$ at $37^{\circ} \mathrm{C}$ prior to addition to a reaction mixture containing $50 \mathrm{mM}$ Tris- $\mathrm{HCl}, 175 \mathrm{mM} \mathrm{NaCl}, 0.5$ $\mathrm{mg} / \mathrm{ml}$ human serum albumin $(\mathrm{pH}$ 7.9) and various concentrations of factor X $(0.005-0.5 \mu \mathrm{M})$. The details are described in Methods Procedures. The results presented are the means \pm SEM of duplicate observations with platelets from three separate normal donors $(0)$ and means of duplicate observations with MS platelets $(\Delta)$. $(B)$ Factor Xa formation by factor IXa in the presence of thrombin-activated platelets and factor VIIIa. Thrombin-stimu-

lated $(0.1 \mathrm{U} / \mathrm{ml})$, gel-filtered platelets $\left(5 \times 10^{7} / \mathrm{ml}\right)$ were preincubated with factor $\mathrm{IXa}(0.01 \mathrm{nM})$ and $5 \mathrm{mM} \mathrm{CaCl}{ }_{2}$ at $37^{\circ} \mathrm{C}$ for $10 \mathrm{~min}$ and with $50 \mathrm{mM}$ PPACK for $2 \mathrm{~min}$ at $37^{\circ} \mathrm{C}$ prior to addition to a reaction mixture containing $50 \mathrm{mM}$ Tris- $\mathrm{HCl}, 175 \mathrm{mM} \mathrm{NaCl}, 0.5 \mathrm{mg} / \mathrm{ml} \mathrm{human}$

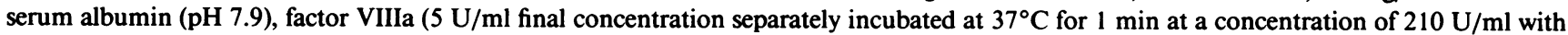
$0.01 \mathrm{U} / \mathrm{ml}$ thrombin before addition to a reaction mixture) and various concentration of factor $\mathrm{X}(0.075-2 \mu \mathrm{M})$. The details are described in Methods. The results presented are the means \pm SEM of duplicate observations with platelets from three separate normal donors $(\bullet)$ and means of duplicate observations with MS platelets ( $(\mathbf{\Lambda})$

shown to be saturating for normal platelets (14) and saturating in our own experiments of factor IXa binding (13) and factor $X$ activation (this paper). It remains to be seen what the effect of higher or lower concentrations of factor VIIIa will have on the differences observed between normal and Scott syndrome platelets.

We conclude that the major difference between normal and Scott syndrome platelets lies in the ability of factor VIIIa, alone or in combination with factor $\mathrm{X}$, to enhance factor IXa binding to normal but not patient platelets to give a more active form of factor IXa. This result suggests the possibility of an impairment of factor VIIIa binding or a diminished affinity of the factor VIIIa-IXa complex for Scott syndrome platelets in the presence of factor $X$. These possibilities will be examined by direct factor VIIIa binding studies to Scott syndrome platelets.

\section{Acknowledgments}

We are grateful to Dr. Harvey J. Weiss for providing access to the patient MS; to Dr. James E. Brown, Cutter Biological, Miles, Inc., Berkeley, CA, for kindly donating purified human factor VIII; and to Patricia Pileggi for her secretarial assistance.

This study was supported by the National Institutes of Health Research grants HL-25661 and HL-36579, and by a grant from The W. W. Smith Charitable Trust.

\section{References}

1. Walsh, P. N., and R. Biggs. 1972. The role of platelets in intrinsic factor Xa formation. Br. J. Haematol. 22:743-760.
2. Walsh, P. N. 1978. Different requirements of intrinsic factor Xa forming activity and platelet factor 3 activity and their relationship to platelet aggregation and release. Br. J. Haematol. 40:311-331.

3. Hultin, M. B. 1982. Role of human factor VIII in factor X activation. J. Clin. Invest. 69:950-958.

4. vanRijn, J., J. Rosing, G. vanDieijen. 1983. Activity of human blood platelets in prothrombin and in factor $\mathrm{X}$ activation induced by ionophore A23187. Eur. J. Biochem. 133:1-10.

5. Rosing, J., L. M. L. vanRijn, E. M. Bevers, G. vanDieijen, P. Comfurius, and R. F. A. Zwaal. 1985. The role of activated human platelets in prothrombin and factor X activation. Blood. 65:319-332.

6. Neuenschwander, P., and J. Jesty. 1988. A comparison of phospholipid and platelets in the activation of human factor VIII by thrombin and factor $\mathrm{Xa}$, and in the activation of factor $\mathrm{X}$. Blood. 72:1761-1770.

7. Miletich, J. P., C. M. Jackson, and P. W. Majerus. 1977. Interaction of coagulation factor Xa with human platelets. Proc. Natl. Acad. Sci. USA. 74:4033-4036.

8. Miletich, J. P., D. W. Majerus, and P. W. Majerus. 1978. Patients with congenital factor $\mathrm{V}$ deficiency have decreased factor $\mathrm{Xa}$ binding sites on their platelets. J. Clin. Invest. 62:824-831.

9. Kane, W. H., M. J. Lindhout, C. W. Jackson, and P. W. Majerus. 1980. Factor Va-dependent binding of factor Xa to human platelets. $J$. Biol. Chem. 255:1170-1174.

10. Dahlback, B., and J. Stenflo. 1978. Binding of bovine coagulation factor Xa to platelets. Biochemistry. 17:4939-4945.

11. Tracy, P. B., J. M. Peterson, M. E. Nesheim, F. C. McDuffie, and K. G. Mann. 1979. Interaction of coagulation factor $V$ and factor Va with platelets. J. Biol. Chem. 254:10354-10361.

12. Tracy, P. B., M. E. Nesheim, and K. G. Mann. 1981. Coordinate binding of factor $\mathrm{Va}$ and factor $\mathrm{Xa}$ to the unstimulated platelet. $J$. Biol. Chem. 256:743-751.

13. Ahmad, S. S., R. Rawala-Sheikh, and P. N. Walsh. 1989. Com- 
parative interaction of factor IX and factor IXa with human platelets. J. Biol. Chem. 264:3244-3251.

14. Nesheim, M. E., D. D. Pittman, J. H. Wang, D. Slonosky, A. R. Giles, and R. J. Kaufman. 1988. The binding of ${ }^{35}$ S-labeled recombinant factor VIII to activated and unactivated human platelets. J. Biol. Chem. 263:16467-16470.

15. Weiss, H. J., W. J. Vicic, B. A. Lages, and J. Rogers. 1979. Isolated deficiency of platelet procoagulant activity. Am. J. Med. 67:206-213.

16. Weiss, H. J., V. T. Turitto, and H. R. Baumgartner. 1986. Role of shear rate and platelets in promoting fibrin formation on rabbit subendothelium: studies utilizing patients with quantitative and qualitative platelet defects. J. Clin. Invest. 78:1072-1082.

17. Miletich, J. P., W. H. Kane, S. L. Hofmann, N. Stanford, and P. W. Majerus. 1979. Deficiency of factor Xa-factor Va binding sites on the platelets of a patient with a bleeding disorder. Blood. 54:10151022.

18. Rosing, J., E. M. Bevers, P. Comfurius, H. C. Hemker, G. v. Dieijen, H. J. Weiss, and R. F. A. Zwaal. 1985. Impaired factor $X$ and prothrombin activation associated with decreased phospholipid exposure in platelets from a patient with a bleeding disorder. Blood. 65:1557-1561.
19. Fraker, P. J., and J. C. Speck. 1978. Protein and cell membrane iodinations with a sparingly soluble chloramide, 1,3,4,6-tetrachloro$3 \alpha, 6 \alpha$-diphenylglycouril. Biochem. Biophys. Res. Commun. 80:849857.

20. Tuszynski, G. P., L. Knight, J. R. Piperno, and P. N. Walsh. 1980. A rapid method for removal of ${ }^{125}$ I-Iodide following iodination of protein solutions. Anal. Biochem. 106:118-122.

21. Scatchard, G. 1949. The attractions of proteins for small molecules and ions. Ann. NY Acad. Sci. 51:660-672.

22. Segel, I. H. 1975. Enzyme Kinetics, Behavior and Analysis of Rapid Equilibrium and Steady-State Enzyme Systems. John Wiley \& Sons, New York. 365-367.

23. Cleland, W. W. 1967. The statistical analysis of enzyme kinetic data. Adv. Enzymol. Relat. Areas Mol. Biol. 29:1-32.

24. Morrison, S. A. 1983. Kinetics of activation of human prothrombin: use of a fluorescein-labeled derivative to obtain kinetic constants as a function of factor $\mathrm{V}$ concentration and activation state. Biochemistry. 22:4053-4061.

25. Jesty, J. 1988. The determination of enzyme-cofactor dissociation constants by kinetic methods: a correction. Thromb. Res. 50:745-746. 